płaszczyznę porozumienia. Dobrze, że podjęła się tego tematu unaoczniając czytelnikowi wagę i znaczenie Kościoła niemieckiego w poszukiwaniu mądrych rozwiązań w interesie wszystkich narodów Europy. Głos biskupów polskich i niemieckich zawsze jako pierwszy ostrzegał przed pobudzaniem resentymentów, jednostronnych interpretacji historycznej i rozdrapywaniu ran. Także w 70-tą rocznicę wybuchu II wojny światowej to oni jako pierwsi wystosowali apel do Europy o rzetelność, odpowiedzialność i obronę prawdy w budowaniu klimatu wzajemnego zaufania dla dobra wspólnej Europy.

IZABELA JANICKA

Poznań

\title{
Razem w sieci. Obywatele wobec zmian klimatycznych i przyszłości energetycznej Unii Europejskiej, pod red. Mikolaja J. Tomaszyka, Adama Jaskulskiego, Wydawnictwo Naukowe WNPiD UAM, Poznań 2008, ss. 118.
}

Bezpieczeństwo energetyczne jest problemem w skali globalnej, a niezakłócony dostęp do surowców energetycznych lub energii staje się kluczowym warunkiem nie tylko rozwoju gospodarek, ale niekiedy bieżącego funkcjonowania w przypadku państw uzależnionych od ich importu. Rosnące potrzeby rozwijających się krajów, deficyt surowców energetycznych, które zlokalizowane są nierównomiernie i w znacznej części w regionach niestabilnych politycznie, wreszcie wykorzystywanie ich w charakterze instrumentu polityki zagranicznej, czego dowodza ostatnie kryzysy wynikające ze wstrzymania dostaw gazu przez Rosję, która za ich pomocą próbuje odbudować swą strefę wpływów. W obliczu tych wydarzeń państwa w pojedynkę i w obrębie większych podmiotów zastanawiają się nad sposobami rozwiązania kwestii zabezpieczenia dostaw surowców energetycznych. Takie działania podejmowały kolejne rządy w Polsce, zarówno na płaszczyźnie wewnętrznej (pomysł budowy elektrowni jądrowej), w stosunkach z innymi państwami (most energetyczny z Litwą, projekt gazociaggu z Norwegii) i w ramach Unii Europejskiej (propozycja solidarności energetycznej).

Próbą przybliżenia tej problematyki jest publikacja Razem w sieci. Obywatele wobec zmian klimatycznych i przyszlości energetycznej Unii Europejskiej, która ukazała się nakładem Wydawnictwa Naukowego Wydziału Nauk Politycznych i Dziennikarstwa Uniwersytetu im. Adama Mickiewicza w Poznaniu. Powstała ona przy wsparciu Wielkopolskiego Punktu Informacyjnego EUROPE DIRECT Urzędu Marszałkowskiego Województwa Wielkopolskiego w Poznaniu.

Książkę zawierającą dziewięć artykułów podzielono na dwie odrębne tematycznie części: Polityka energetyczna i klimatyczna Unii Europejskiej oraz Polska wobec polityki energetycznej i klimatycznej Unii Europejskiej. Pierwsza przybliża działania, jakie podjęła Wspólnota na rzecz zapewnienia konkurencyjności na rynku energetycznym i bezpieczeństwa, które mają zapewnić trwały rozwój gospodarczy. Interesująco prezentuje się przegląd legislacji w tym zakresie oraz działania podjęte przez państwa członkowskie w obszarze instytucjonalnym. Wśród celów polityki energetycznej Unii Europejskiej wymienia się: stworzenie wewnętrznego rynku, który zagwarantuje bezpieczeństwo dostaw i solidarność państw członkowskich na rynku energii i gazu, stawienie czoła skutkom zmian klimatycznych oraz wspólną politykę energetyczną w odniesieniu do państw trzecich. Ważną rolę w podniesieniu rangi tych zagadnień odegrała Polska, która akcentowała konieczność solidarnego i wspólnego rozwiązywania problemów energetycznych.

Niezwykle istotne dla realizacji tych celów jest rzeczywista liberalizacja rynku energetycznego, czemu poświęcono jeden z artykułów. Ta dziedzina gospodarki nadal pozostaje pod zbyt dużą kontrolą ze strony państw, co zakłóca konkurencję skutkując choćby wyższymi cenami 
i utrudnionym dostępem dla innych podmiotów zmniejszając - ze względu na brak presji konkurencyjnej - efektywność tego sektora. Przeprowadzenie procesu liberalizacji będzie sprawdzianem skuteczności unijnych instytucji, bowiem silna jest niechęć do rozbicia narodowych monopoli w tym obszarze. Dodatkowym czynnikiem utrudniającym to zadanie jest niechęć Rosji do prowadzenia rozmów z Unią Europejską reprezentującą wszystkie państwa członkowskie, wybierając te, które są jej bardziej przychylne. W ten sposób rosyjskie firmy są już obecne w wielu krajach.

Wśród rozwiązań problemu kurezących się zasobów suroweów energetycznych wskazuje się energetykę jądrową i energię odnawialną, które również analizują autorzy publikacji. Obie związane są ze znacznymi wydatkami, ta pierwsza dodatkowo obciążona jest pewnym ryzykiem, związanym chociażby z bezpieczeństwem instalacji i koniecznością przechowywania odpadów. Rosnące zapotrzebowanie na energię oznacza wyższą emisję do atmosfery szkodliwych związków chemicznych, dlatego też walka z efektem cieplarnianym jest jednym z priorytetowych celów Unii Europejskiej w zakresie polityki gospodarczej. Zarówno Unia, jak i wszystkie państwa członkowskie są stronami Konwencji Klimatyeznej i Protokołu z Kioto, które wśród celów wskazują znaczące ograniczenie emisji gazów cieplarnianych w najbliższych latach.

W części dotyczącej Polski, znalazły się artykuły przybliżające kwestie związane z gwarancją bezpieczeństwa energetycznego, jaką dla Polski stanowić może Unia Europejska i zobowiązaniami w dziedzinie ochrony środowiska wynikającymi z członkostwa w tej organizacji. Rządowe projekty przewidują dywersyfikację źródeł dostaw surowców energetycznych, która ma się odbywać zarówno na płaszczyźnie wspólnotowej, jak i poprzez stosunki bilateralne (na przykład z Ukraina, Gruzją, Azerbejdżanem). Na arenie unijnej Polska jest rzecznikiem solidarnej i bardziej zdecydowanej polityki wobec Rosji, wyjaśniając że jest to państwo nieprzewidywalne. W publikacji traktującej o takiej tematyce nie mogło zabraknąć artykułu dotyczącego Gazociagu Północnego, który wzbudza tak wiele kontrowersji w Polsce. Wskazuje się nie tylko na niemiecko-rosyjsko porozumienie ,ponad głowami” Polaków, ale również zagrożenia ekologiczne związane $\mathrm{z}$ budową rurociągu na dnie Bałtyku (zobacz raport eurodeputowanego Marcina Libickiego). Przede wszystkim jednak inwestycję tę przedstawia się jako argument za solidarną polityką energetyczną wszystkich państw członkowskich, krytykując przy okazji rząd niemiecki. Ostatnie dwa artykuły to case-study: energetyczna efektywność a odnawialne źródła energii na przykładzie gminy Słubice oraz model dywersyfikacji zaopatrzenia w gaz na przykładzie złóż zlokalizowanych w Kościanie.

Przygotowana przez Wydział Nauk Politycznych i Dziennikarstwa UAM publikacja dotyczy niezwykle aktualnej problematyki. Od kilku lat niemal każdej zimy pojawiają się informacje o możliwości wstrzymania dostaw gazu przez Rosję, co uderza we wszystkie państwa czerpiące z rurociagu. O znaczeniu dostępu do surowców energetycznych świadczy rosnąca aktywność Rosji i państw zachodnich na Kaukazie, a słowo dywersyfikacja na stałe już zagościło w języku debaty publicznej. W Polsce odżyła dyskusja nad sensownością budowy elektrowni jądrowej, coraz częściej zwraca się uwagę na konieczność oszczędzania energii i rozwoju sektora energii odnawialnej. 